\title{
PENINGKATAN HASIL BELAJAR MATA PELAJARAN PENDIDIKAN KEWARGANEGARAAN MENGGUNAKAN STRATEGI PEMBELAJARAN PENINGKATAN KEMAMPUAN BERFIKIR (SPPKB) PADA SISWA KELAS VII C SMP NEGERI 1 KETAPANG
}

\author{
Syarif Firmansyah ${ }^{1}$, Minarni ${ }^{2}$ \\ ${ }^{1,2}$ Program Studi PPKN Fakultas Ilmu Pendidikan dan Pengetahuan Sosial IKIP PGRI Pontianak \\ Jl. Ampera Nomor 88 Pontianak-78116, Telepon (0561) 748219 Fax. (0561) 6589855 \\ Email: firman230684@gmail.com
}

\begin{abstract}
Abstrak
Tujuan penelitian adalah ingin mengetahui cara dan proses dalam peningkatan hasil belajar siswa menggunakan strategi pembelajaran peningkatan kemampuan berfikir (SPPKB) di kelas VII SMP Negeri 1 Ketapang. Peningkatan hasil belajar setelah diterapkan strategi pembelajaran peningkatan kemampuan berfikir pada mata pelajaran pendidikan kewarganegaraan, hasil belajar siswa kelas VII SMP Negeri 1 Ketapang setelah guru PKn menerapkan strategi pembelajaran peningkatan kemampuan berfikir (SPPKB). Subyek penelitian 35 orang siswa dan 1 orang guru PKn. Prosedur penelitian menggunakan siklus yang terdiri dari perencanaan, pelaksanaan, observasi, dan refleksi. Teknik pengumpulan data yang digunakan adalah observasi langsung, teknik pengukuran dan studi documenter. Hasil penelitian menunjukanbahwa secara umum penerapan strategi pembelajaran peningkatan kemampuan berfikir di kelas VII dilakukan dengna baik. Secara khusus: bahwa perencanaan dilakukan terlebih dahuu oleh guru PKn dan mengacu kepada kurikulum K13, pelaksanaan strategi pembelajaran peningkatan kemampuan berfikir di lakukan dalam 2 siklus dan pelaksanan berjalan dengan baik dan lancar, hasil belajar siswa di kelas VII sebelum menggunakan strategi pembelajaran peningkatan kemampuan berfikir hanya mencapai $25,71 \%$ dengan nilai rata-rata 63 , setelah diterapkan strategi pembelajaran peningkatan kemampuan berfikir pada (siklus 1) 62,86\% dengan nilai rata-rata 73, dilanjutkan pada (siklus II) hasil belajar mengalami peningkatan yaitu $82,86 \%$ dengan nilai rata-rata 80 .
\end{abstract}

Kata Kunci: strategi pembelajaran peningkatan kemampuan berfikir, hasil belajar.

\begin{abstract}
The purpose of the study is to know the ways and processes in improving student learning outcomes using learning strategies to improve thinking skills (SPPKB) in class VII SMP Negeri 1 Ketapang. Improvement of learning outcomes after application of learning strategies to improve thinking skills in the subjects of civic education, student learning outcomes of grade VII SMP Negeri 1 Ketapang after the Civics teachers apply learning strategies to improve thinking skills (SPPKB). The subjects of the study were 35 students and 1 Civics teacher. The research procedure uses a cycle consisting of planning, execution, observation, and reflection. Data collection techniques used are direct observation, measurement techniques and documentary studies. The results showed that in general the application of learning strategies to improve thinking skills in class VII done dengna good. Specifically: that the planning is done first by the teacher of Civics and referring to the curriculum K13, the implementation of learning strategies to improve thinking skills are done in 2 cycles and the implementation runs well and smoothly, the results of student learning in class VII before using learning strategies to improve thinking skills reached $25.71 \%$ with an average score of 63, after applied learning strategy improvement thinking ability at (cycle 1) $62,86 \%$ with average value 73 , continued at (cycle II) learning result have increase that is $82,86 \%$ with an average value of 80 .
\end{abstract}

Keywords: learning strategy to improve thinking ability, civic education, learning result.

\section{PENDAHULUAN}

Pendidikan adalah usaha sadar dan terencana untuk mewujudkan suasana belajar dan proses pembelajaran agar peserta didik secara aktif mengembangkan potensi dirinya untuk memiliki kekuatan spiritual keagamaan, akhlak mulia, serta keterampilan yang diperlukan dirinya, masyarakat, bangsa dan bernegara. (pasal 1 ayat 1 UU sistem pendidikan nasional, 2007). 
Pendidikan mempunyai peranan yang sangat penting untuk menjamin perkembangan dan kelangsungan hidup suatu bangsa. Karena kualitas kehidupan bangsa sangat ditentukan oleh faktor pendidikan. Dalam hal ini pembaharuan pendidikan harus selalu dilakukan untuk meningkatkan kualitas pendidikan karena kemajuan suatu bangsa hanya dapat dicapai melalui penataan-penataan pendidikan yang baik. Upaya meningkatkan mutu pendidikan diharapkan dapat meningkatkan harkat dan martabat manusia Indonesia. Pendidikan harus terbuka terhadap perubahan dan perkembangan zaman. Penyelenggaraan pendidikan tidak lepas dari tujuan dan fungsi pendidikan nasional UU No.2 tahun 2003 tentang sistem pendidikan nasional pasal 3, yaitu: Pendidikan nasional berfungsi mengembangkan kemampuan dan membentuk watak serta peradapan bangsa yang bermartabat dalam rangka mencerdaskan kehidupan bangsa, bertujuan untuk berkembangnya peserta didik agar jadi manusia yang beriman dan bertakwa kepada tuhan yang maha esa, berakhlak mulia, berilmu, cakap, kreatif, mandiri, dan menjadi warga Negara yang baik demokratis serta bertanggung jawab.

Melihat fungsi dan tujuan pendidikan nasional, pendidikan pancasila dan kewarganegaraan merupakan salah satu mata pelajaran yang membekali siswa dengan pengetahuan dan kemampuan dasar berkenaan dengan hubungan antar warga Negara yang baik dan dapat dianlkan oleh bangsa dan Negara kesatuan republic Indonesia.

Proses pembejaran dikelas sangat terpusat pada guru (teacher centered), sehingga partisipasi aktif siswa dalam pembelajaran tidak muncul. Sebagai akibatnya, kegiatan belajar mengajar lebih menekankan pada pengajaran dari pada pembelajaran. Pembelajaran dikelas harus dapat meningkatkan kreativitas dan daya inovatif siswa, dengan cara mendoronng siswa agar dapat menghasilkan sesuatu yang terbaik. Artinya, siswa diberi kebebasan untuk berpartisipasi secara aktif dalam proses pembelajaran di kelas melalui pengembangan daya inovatif dan kreatifitasnya.

Model pembelajaran yang tepat untuk mencapai tujuan pendidikan kewarganegaraan adalah model yang bersifat diallogis-kritis, pengalaman langsung (direct experiences), kolaboratif, dan kooperatif. Model pembelajran seperti ini menekankan pada tiga ranah pembelajaran, yaitu: kognitif, afektif, dan psikomotorik. Hal ini sejalan dengan apa yang dinyatakan kirschenbaum (1995: 24-26) bahwa aspek citizenship education meliputi: knowledge, appreciation, critical thinking skills, communication skills, cooperation skills, and conflict resolution skills. (pengetahuan, apresiasi, keterampilan kritis, keterampilan komunikasi, keterampilan kerja sama, dan resolusi konflik keterampilan).

Dalam proses pembelajaran, hasil belajar merupakan suatu hal yang diperoleh attau dicapai siswa. Abdurahman (Asep, 2013: 14) mengemukakan bahwa: "hasil belajar adalah kemampuan yang diperoleh anak setelah melalui kegiatan belajar". Adapun hasil belajar dari penilaian ini adalah kemampuan kognitif, dimana siswa dapat mengetahui, memahami, dan menerapkan. 
Mengacu pada pendapat tersebut, peneliti tertarik untuk melakukan penelitian di SMP Negeri 1 Ketapang, karena pada kenyataan masih banyak siswa khususnya dikelas VII C SMP Negeri 1 Ketapang yang nilainya dibawah kriteria ketuntasan minimal (KKM) yaitu 75 Hal ini disebabakan pembelajaran masih bersifat teacher centerd ( pembelajarn terpusat pada guru) selain itu ada juga faktor yang berasal dari siswa itu sendiri diantaranya kurangnya kemampuan berfikir siswa dan kurangnya antusias siswa untuk bertanya sebagian siswa cenderung sibuk sendiri dan sebagiannya lagi ribut saat kegiatan pembelajaran.

Sebagaimana penelitian yang dilakukan Ahmad Tohri (2011: 105) yang menunjukan bahwa dengan menggunakan strategi pembelajaran peningkatan kemampuan berfikir menngkatkan prestasi belajar siswa di kelas X SMA Wanasaba. Hal tersebut dilihat dari hasil observasi aktivitas siswa diperoleh persentase siklus pertama jumlah siswa yang tuntas sebanyak 63,41\% dan hasil observasi aktivitas belajar siswa pada siklus I pertemuan pertama dan kedua adalah 2,84 dan 2, 89 yang berkategori aktif. Sedangkan pada siklus kedua jumlah siswa yang tuntas sebanyak $87,80 \%$ dan hasil observasi aktivitas belajar siswa pada siklus II pertemua pertama dan kedua adalah 3,26 dan 3,29 yang berkategori sangat akktif.

Berdasarkan hasil-hasil penelitian tersebut dapat di asumsikan bahwa dengan menerapkan strategi pembelajaran peningkatan kemampuan berfikir dapat meningktakan aktivitas belajar siswa yang cederung pasif untuk bertanya . sehingga dapat diartikan bahwa strategi pembelajaran peningkatan kemampuan berfikir dapat menjadi pilihan dalam mengatasi permasalahan pembelajaran PKn yang dihadapi guru dan siswa, yakni masalah hasil belajar siswa di kelas VII C SMP Negeri 1 Ketapang.

\section{METODE}

Metode yang akan digunakan pada penelitian ini adalah metode penelitian tindakan. Menurut Sumandi Suryabrata (dalam Muhammad Asrori, 2009: 92) mengemukakan bahwa, "penelitian tindakan adalah penelitian yang bertujuan mengembangkan keterampilan baru atau cara pendekatan baru untuk memecahkan masalah dengan penerapan langsung di dunia kerja atau dunia katual lain".

Bentuk penelitian yang digunakan dalam penelitian ini adalah penelitian tindakan kelas (Classroom Action Research). Sedangkan menurut Iskandar (2009: 20) mengatakan bahwa "penelitian tindkana kelas (PTK) merupakan bagian dari penelitian tindakan (action research) yang dilakukan oleh guru dan dosen di kelas tempat ia mengajar yang bertujuan untuk memperbaiki dan meningkatkan kualitas dan kuantitas proses pembelajaran”.

Penelitian tindakan kelas adalah sebagai proses pengkajian masalah didalam kelas berupa tindakan yang terencana untuk memecahkan permasalahan dan sekaligus meningkatkan kualitas yang 
dapat disarankan implikasinya oleh subjek yang diteliti. Adapun menurut Arikunto (2014:16) model penelitian tindakan dengan empat langkah yaitu: perencanaan (planning), tindakan (acting). Pengamatan (observing), dan refleksi (reflecting).

Subjek penelitian siswa kelas VII C SMP Negeri 1 Ketapang yang berjumlah 35 orang siswa. Teknik pengumpulan data menggunakan teknik observasi langsung, komunikasi langsung, teknik pengukuran, dan teknik studi documenter dengan alat pengumpul data menggunakan pedoman observasi, panduan wawancara, tes hasil belajar,dokumentasi. Teknik analisi data menggunakan data kualitatif dan data kuantitatif.

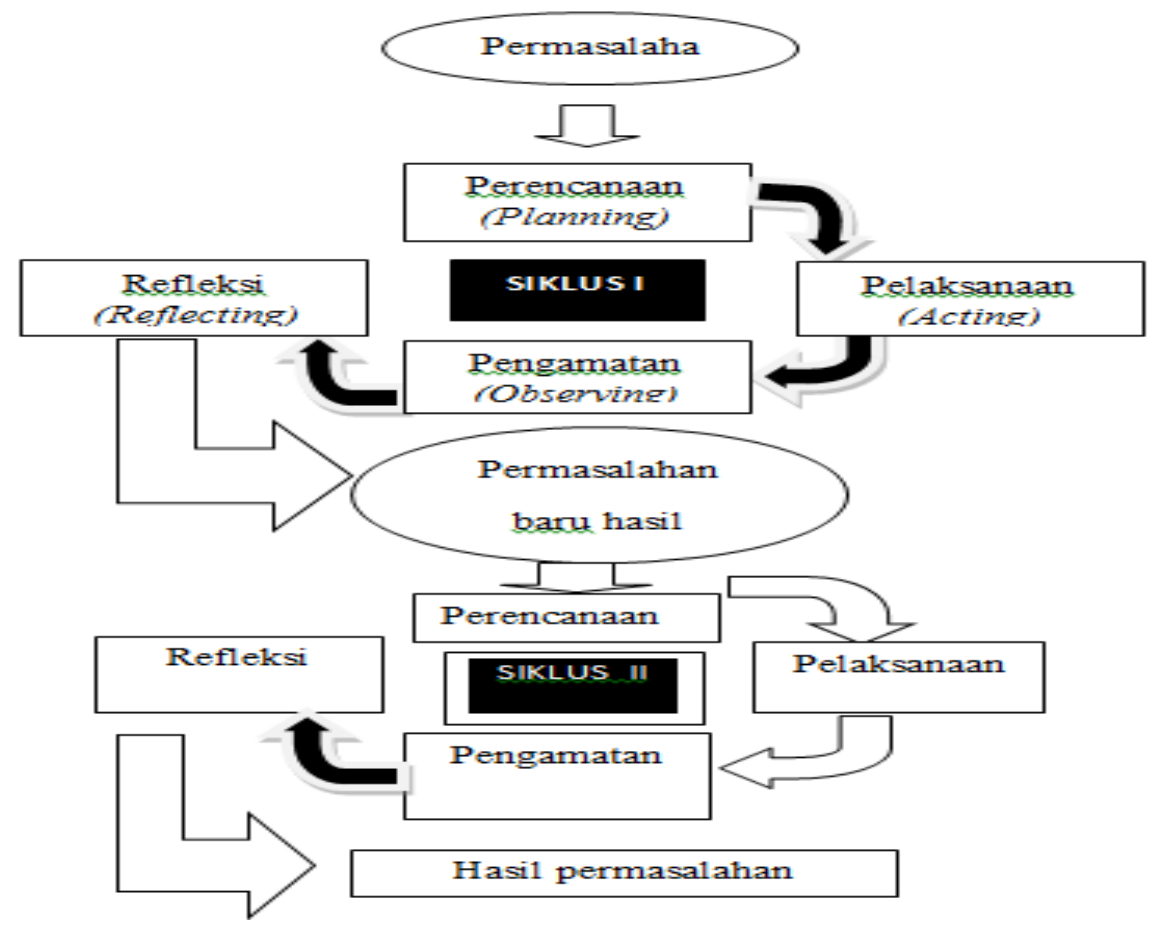

\section{HASIL DAN EMBAHASAN}

perencanaan pembelajaran pendidikan kewarganegaraan dengan strategi pembelajaran peningkatan kemampuan berfikir (SPPKB) untuk meningkatkan hasil belajar siswa di Kelas VII SMP Negeri 1 Ketapang.

Berdasarkan temuan dilapangan bahwa, guru dalam merencanakan pembelajran sudah disepakati antara peneliti dan guru kolaborasi. Pembelajaran PPKn dengan menggunakan strategi pembelajaran peningkatan kemampuan berfikir (SPPKB) Pada mata pelajaran pendidikan pancasila dan kewarganegaraan di kelas VII C SMP Negeri 1 Ketapang. Tujuan atau hasil yang ingin dicapai dalam proses perencanaan pembelajaran pada umumnya untuk mencapao hasil belajr atau tujuan belajar yang optimal dalamproses perencanaan tersebut, maka proses belajar mengajar harus dilakukan dengan sadar atau terencana. Guru sebelum melakukan pembelajran telah merencanakan perangkat-perangkat pembelajaran seperti silabus, RPP. Dimana dalamRPP terdiri dari guru PPKn 
telah menyiapkan materi pembelajaran, guru PPKn juga menyiapkan materi pembelajaran, guru PPKn juga menyiapkan strategi pembelajran peningkatan kemampuan berfikir (SPPKB) yang sesuai dengna RPP, kemudian guru juga merumuskan pembelajran yang sesuai dengan indikator pembelajaran, guru PPKn juga sudah menyiapkan post test. Kemudian dari pada itu, guru PPKn juga menggunakan buku paket pendidikan pancasila dan kewarganegaraan kelas VII Untuk SMP. Tujuan yang ingin dicapai dalam proses pembelajaran adalah mencapai tujuan belajajar yang optimal dalam proses membuat perencanaan sebelum mengajar, oleh karenanya pelaksanaan perencanaan harus dilakukan secara sadar dan terencana.

Berdasarkan temuan di lapangan dapat disimpulkan bahwa, dalam perencanaan pembelajran yang dilakukan oleh penelitidan guru kolaborasi sudah dilakukan denan baik, dari merancang silabus,RPP, menyampaikan materi, menggunakan strategi pembelajarn peningkatan kemampuan berfikir (SPPKB) yang diterapkan dalamproses pembelajran. Karena dengan merancang kegiatan pembejaran di kelas dapat berjalan sesuai dengan tujuanyang ingin dicapai yakni perubahan hasil belajar yang lebih baik dari sebelumnya,yaitu sebelum menggunkan strategi pembelajaran penigkatan kemampuan berfikir (SPPKB).

\section{pelaksanaan pembelajaran pendidikan kewarganegaraan dengan Strategi pembelajaran peningkatan kemampuan berfikir (SPPKB) untuk meningkatkan hasil belajar siswa di Kelas VII SMP Negeri 1 Ketapang \\ Pra Siklus}

Berdasarkan temuan dilapangan bahwa, pelaksanaan pembelajran sebelum menggunakn stategi pembelajran peningkatan kemampuan berfikir di kelas VII SMP Negeri 1 Ketapang. Pembelajaran belum bisa dikatakan baik, dari hasil observasi yang dilakukasn oleh peneliti terhadap aktifitas guru PPKn dalam melaksanakan pembelajaran pra siklus, guru tidak menyampaikan tujuan pembelajran, sedangkan hasil pemgamatan terhadap siswa pada pra siklus pada dasenya pembelajran berjalan dengan efektif hanya saja pembelajaran PPKn menonton saja kepada guru dan membuat pelajran PPKn tidak menarik perhatian siswa yang tidak memperhatikannya penjelasan guru.

Kemudian dari pada itu hasil post test siklus terdapat siswa yang mendapat nilai KKM berjumlah 9 oranag siswa dari 35 oranag siswa, dan 26 orang siswa yang tidak mencapai nilai KKM atau dibawah KKM.

Jika siswa berhasil mencapai $\geq 60 \%$ maka tingkatketuntasan belajar tercapai, namu pada kenyataanya di lapangan ketuntasan belajr siswa hanya mencapai 25,71\% maka dapat disimpulkan ketuntasan belajar siswa belum tercapai dengan kriteria penilian SMP Negeri 1 Ketapang dan dapatdikatakan nilai PPKn siswa kelas VII SMP Negeri 1 Ketapang dapat dikategorikan rendah. 


\section{Siklus 1}

Berdasarkan temuan dilapangan bahwa guru dalam melaksanakn kegiatan pembelajaran dengan menggunkan strategi pembelajaran peningkatan kemampuan berfikir (SPPKB) pada mata pelajaran pendidikan pancasila dan kewarganegaraan di kelas VII SMP Negeri 1 Ketapang. Pelaksanaan Pembelajran pada sikllus I yang dilaksanakan guru PPKn sudah cukup baik, dari obeservasi lapangan terhadap aktifitas guru PPKn dalam melaksanakan pembelajaran secara umum telah melaksanakan rancangan pelaksanaan pembelajaran yang dibuat oleh peneliti untuk guru, namun guru terburu-buru dalam menyampaikan materi danguru kurang memberikan penguatan atau motivasi terhadap siswa.

Selai itu dari hasil observasi terhadap aktifitas siswa dalam mengikuti pembelajarn PPKn dengan penerapan strategi pembelajaran peningakatan kemampuan berfikir (SPPKB) yang diterapkan oleh guru menunjukan semua siswa hadir dalam mengikuti pembelajaran dan menunjukan keseriusan siswa dalam memcahkan persoalan yang diberikan guru dan sebagian siswa masih merasa canggung dalam menjawab pertanyaan.

Dari hasil belajar post tes siklus I hasil belajar siswa bisa dilakukan baik dilihat dari jumlah sisea yang mendapat nilai diatas KKM berjumlah 22 orang dari 35 orang siswa dengan jumlah persentase ketuntasan belajar 62,86\%. Berdasarkan hasil tindakan pada siklus I bahwa hasil belajar yang di dapat telah mencapai indikator yang ditentukan yaitu $(\geq 60 \%)$ tetapi hasil tersebut belum maksimal dan masih banyak kekurangan dan hasil kesepakatan antara guru PPKn sebagaimitra kolaborasi danpeneliti memutuskan untuk melanjutkan ke siklus II.

\section{Siklus II}

Berdasarkan temuan dilapangan, bahwa menunjukan pada pelaksanaan sikllus II melalui strategi pembelajaran peningkatan kemampuan berfikir (SPPKB) sudah dilakukan dengan baik dan hasil belajarnya pun baik.

Dari hasil observasi aktifitas siswa menunjukan keaktifan siswa dikelas yakni, siswa tidak canggung lagi bertanaya dan menjawab persolan yang diberikan guru. Sedangkan pada lembar observasi gurupada siklus II menunjukan bahwa guru PPKn telah menjalankan rancangan pelaksanaan pembelajaran, guru sudah tidak kelihatan terburu-buru lagi dalam menyampaikan materi danguru jugateah memberikan penghargaan atau motivasi kepada siswa yang teah menjawab maupun bertanya. 
Olehkarena itu, pada hasil belajar siswa pun adanya peningkatan yang sangat baik. Dimana siswa yang mendapatkan nilai di atas KKM berjumlah 29 orang dari 35 orang siswa. Ketuntasan hasil belajar mencapai $82,86 \%$ dapat dikategorikan sangat tinggi. Berdasarkan hasil tindakan pada siklus II yang menunjukan bahwa hasil belajar telah mencapai indikator keberhasilan ( $\geq 60 \%)$ sehingga peneliti danguru PPKn sebagai mitra kolaborasi menuntaskan untuk menerhentikan sampai siklus II.

\section{Hasil belajar Siswa Melalui Strategi Pembelajaran Peningkatan Kemampuan Berfikir (SPPKB) Pada Mata Pelajaran Pendidikan Kewarganegaraan Di Kelas VII SMP Negeri 1 Ketapang.}

Berdasarkan temuan penelitian bahwa proses pembelajran yang dilakukan oleh guru kolaborasi pada prasiklus diketahui jumlah siswa yang tuntas yaitu 9 orang siswa dari 35 orang siswa dengna persentase ketuntasan $25,71 \%$ hal ini disebabkan belum dilaksankannya strategi pembelajaran peningkatan kemampuan berfikir (SPPKB) dimana kegiatan belaja rmengajar siswa belum optimal dan metode yang diterapkan guru pada prasiklus tidak membuat siswa semangat dalam mengikuti proses belajar dan mengajar sehingga pada saat siswa diberikan soal post tes hasilnya tidak sesuai dengan apa yang diharapkan. Pada saat pelaksanaan siklus I siswa yang tuntas 22 orang siswa dari 35 orang siswa dengan persentase ketuntasan $62,86 \%$ hal ini dikarenakan siswa mulai tertarik dengan strategi pembelajaran peningkatan kemampuan berfikir (SPPKB), sehingga hasil post sehingga hasil post test yang diberikan meningkat dan mencapai indikator yang diharpakan. Tetapai di dalam kegiatan belajar mengajar pada siklus I masih terdapat kekuranganan dalam melaksanakan langkahlangkah pembelajaran melalui strategi pembelajaran peningkatan kemampuan berfikir (SPPKB), sehingga peneliti dan guru masih ingin mengetahui tingkat keberhasilan siswa dengan melakukan tindakan selanjutnya. Maka, peneliti dan guru PPKn sebagai mitra kolaborasi melaksanakan siklus II. Pada saat pelaksanaan siklus II siswa yang tuntas berjumlah 29 orang siswa dari 35 orang siswa dengan persentase ketuntasan $82,86 \%$ hal ini dikarenakan siswa sudah terbiasa dengan strategi pembelajaran peningktan kemampuan berfikir (SPPKB) yang diterapkan pada siklus sebelumnya, sehingga siswa sudah menguasai materi.

Dari prasikllus, siklus I dan siklus II peneliti banyak menemukan perubahan pada perolehan hasil belajar siswa. Perubahan tersebut dikarenakan adanya tindakan dari strategi pembelajaran peningkatan kemampuan berfikir (SPPKB) dalam meningkatkan hasil belajar siswa selama kegiatan belajar mengajar di kelas berlangsung. peningkatan ketuntasan belajar siswa kelas VII C setelah diberikan tindakan dapat ditampilkan pada grafik berikut ini: 


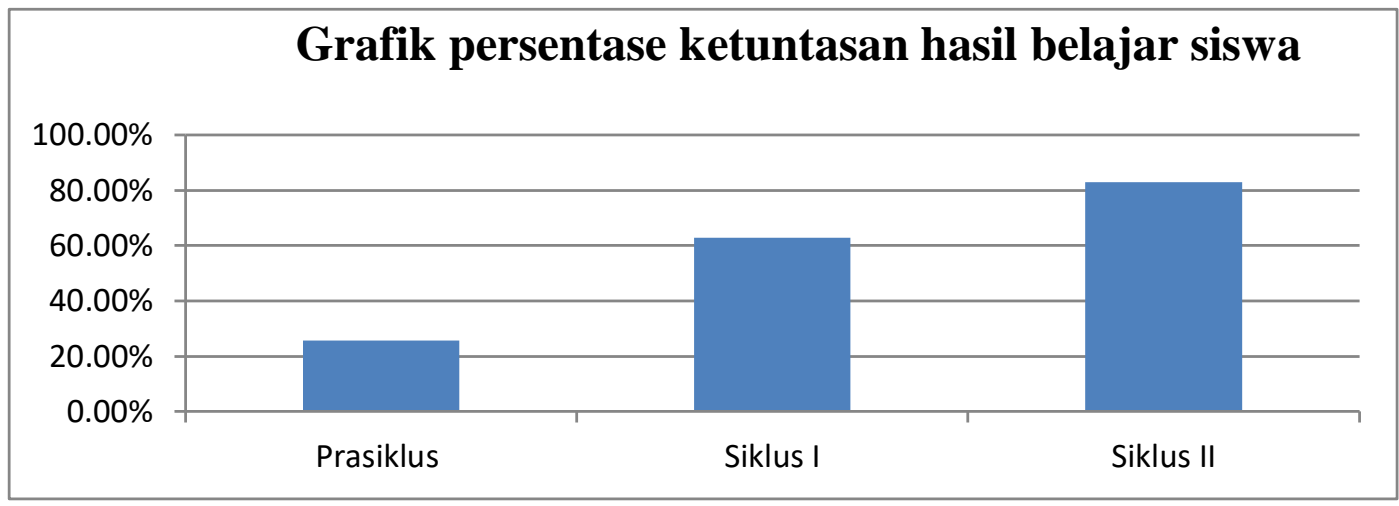

Dapat disimpulkan bahwa dengan melaksanakan tindakan dengan menggunakan strategi pembelajaran peningkatan kemampuan berfikir (SPPKB) Pada mata pelajaran pendidikan kewaarganegaraan dapat meningkatkan hasil belajar siswa kelas VII C SMP Negeri1 Ketapang.

\section{SIMPULAN}

Berdasarkan hasill penelitian yang telah dilakukan oleh peneliti, dapat disimpullkan bahwa penerapan strategi pembelajaran peningkatan kemampuan berfikir dalam proses pembelajaran pendidikan kewarganegaraan pada materi perumusan dan penetapan pancasila sebagai dasar negara di kelas VII C SMP Negeri 1 Ketapang dilaksanakan dengan baik, langkah - langkah pelaksanaan strategi pembelajaran peningkatan kemampuan berfikir telah dijalankan sesuai perencanaan sehingga hasil belajar siswa meningkat dilihat dari hasil tes pada siklus I dan siklus II telah mencapai indicator keberhasilan yang ditemukan oleh peneliti.

\section{DAFTAR PUSTAKA}

Darmadi, Hamid (2010). Pengantar Pendidikan Kewarganegaraan. Bandung: Alfabeta. (2013). Urgensi Pendidikan Pancasila dan kewarganegaraan di Perguruan Tinggi. Bandung: Alfabeta.

(2014). Metode penelitian pendidikan dan sosial. Bandung: Alfabeta.

Ekawarna (20011). Penelitian Tindakan Kelas. Jakarta: Gaung Persada.

Hadi. A (2005). Metode Penelitian Pendidikan. Bandung: CV Pustaka Setia.

Sudjana, N (2009). Penilaian Hasil Proses Belajara Mengajar . Bandung: PT Remaja Rosda karya. Sugiyono (2011). Metode Penelitian Pendidikan Kuantitatif, Kuantitatif, R\&D. Bandung: alfabeta. Suharsimi, A. (2010) Prosedur penelitian satuan pendekatan praktik. Jakarta; PT. Rineka Cipta. Sanjaya. W (2011). Strategi Pembelajaran Berorientasi Standar Proses Pendidikan. Jakarta: Kencana

Undang - Undang Republik Indonesia No 20 tahun 2003. Tentang Sistem Pendidikan Nasional 